\title{
Protocol
}

\section{Purification and Culture of Retinal Ganglion Cells from Rodents}

\author{
Alissa Winzeler and Jack T. Wang ${ }^{1}$ \\ Department of Neurobiology, Stanford University School of Medicine, Stanford, California 94305
}

Here we describe methods for acute purification of retinal ganglion cells (RGCs) from rodent retina by immunopanning, followed by culture in serum-free medium. Though the method was initially established and verified with rats, we have included modifications for the purification of mouse RGCs. This protocol is written for isolation of cells from one litter of pups. All of the volumes and numbers of panning plates should be scaled according to the number of litters used, particularly for rat RGCs.

\section{MATERIALS}

It is essential that you consult the appropriate Material Safety Data Sheets and your institution's Environmental Health and Safety Office for proper handling of equipment and hazardous material used in this protocol.

RECIPES: Please see the end of this article for recipes indicated by $<R>$. Additional recipes can be found online at http://cshprotocols.cshlp.org/site/recipes.

\section{Reagents}

\section{BSA (4\%)}

To prepare a stock of 4\% BSA in Dulbecco's phosphate-buffered saline (D-PBS), dissolve $8 \mathrm{~g}$ of BSA (SigmaAldrich A4161) in $150 \mathrm{~mL}$ of D-PBS (HyClone SH30264.01) at $37^{\circ} \mathrm{C}$. Adjust the pH to 7.4 with $\sim 1 \mathrm{~mL} \mathrm{of} 1 \mathrm{~N}$ $\mathrm{NaOH}$. Bring the volume to $200 \mathrm{~mL}$. Filter through a $0.22-\mu \mathrm{m}$ filter. Store in $1-\mathrm{mL}$ aliquots at $-20^{\circ} \mathrm{C}$. (Dilute BSA stock to $0.2 \%$ in D-PBS just before use.)

DNase $(0.4 \%)$

To prepare a $0.4 \%$ stock of DNase in Earle's balanced salt solution (EBSS), add $1 \mathrm{~mL}$ of EBSS (Sigma-Aldrich E6267) per 12,500 units of DNase (Worthington LS002007). Keep on ice. Filter-sterilize, and store in 200- $\mu \mathrm{L}$ aliquots at $-20^{\circ} \mathrm{C}$.

Dulbecco's phosphate-buffered saline (D-PBS) with phenol red Add $500 \mu \mathrm{L}$ of $0.5 \%$ phenol red (Sigma-Aldrich P0290) per $500 \mathrm{~mL}$ bottle of Dulbecco's phosphate-buffered saline (D-PBS; HyClone SH30264.01).

Earle's Balanced Salt Solution $\left(\mathrm{Ca}^{2+}-\right.$ and $\mathrm{Mg}^{2+}$-free) (EBSS; Invitrogen 14155-063)

Ethanol-washed glass coverslips $<\mathrm{R}>$

Fetal calf serum (FCS) (Gibco 10437-028)

Prepare $50-\mathrm{mL}$ aliquots of FCS. Heat-inactivate aliquots for $30 \mathrm{~min}$ at $55^{\circ} \mathrm{C}$, and then store at $-20^{\circ} \mathrm{C}$.

High-ovomucoid (high-ovo) stock solution $(6 \times)<\mathrm{R}>$

\footnotetext{
${ }^{1}$ Correspondence: jtw@stanford.edu

(C) 2013 Cold Spring Harbor Laboratory Press

Cite this article as Cold Spring Harb Protoc; 2013; doi:10.1101/pdb.prot074906
} 
A. Winzeler and J.T. Wang

Immunopanning purification reagents

For purification of rat RGCS

Goat anti-mouse IgM, $\mu$-chain specific (Jackson ImmunoResearch 115-005-020)

Goat anti-rabbit IgG (H+ L) (Jackson ImmunoResearch 111-005-003)

Rabbit anti-rat macrophage polyclonal antibody (Cedarlane CLAD51240)

Thy 1.1 hybridoma supernatant (see Culturing Hybridoma Cell Lines for Monoclonal Antibody Production [Winzeler and Wang 2013a])

For purification of mouse RGCS

Goat anti-mouse IgG + IgM (H + L) (Jackson ImmunoResearch 115-005-044)

Lectin from Bandeiraea simplicifolia (BSL-1; Vector Labs L-1100) $(5 \mathrm{mg} / \mathrm{mL}$ )

Mouse anti-mouse Thy1.2 (CD90) IgM (Serotec MCA02R)

Insulin stock $(0.5 \mathrm{mg} / \mathrm{mL})<\mathrm{R}>$

L-cysteine (Sigma-Aldrich C7477)

Laminin (mouse) (Cultrex; R\&D Systems 3400-010-01)

Thaw mouse laminin $(1 \mathrm{mg} / \mathrm{mL})$ at $4^{\circ} \mathrm{C}$. Make $10-\mu \mathrm{L}$ aliquots and store at $-80^{\circ} \mathrm{C}$.

Low-ovomucoid (low-ovo) stock solution $(10 \times)<\mathrm{R}>$

$\mathrm{NaOH}(1 \mathrm{~N})$

Neurobasal medium (Gibco 21103-049)

Papain (Worthington Biochemical LS003126)

Poly-D-lysine stock (PDL) $(1 \mathrm{mg} / \mathrm{mL} ; 100 \times)$

Add $5 \mathrm{~mL}$ of $\mathrm{H}_{2} \mathrm{O}$ to a 5-mg bottle of poly-D-lysine (PDL; Sigma-Aldrich P6407). Filter through a 2- $\mu m$ filter. Make $100-\mu \mathrm{L}$ aliquots and store at $-20^{\circ} \mathrm{C}$. Dilute stock to $1 \times$ in sterile $\mathrm{H}_{2} \mathrm{O}$ before use.

Rat or mouse pups (P7)

RGC growth medium $<\mathrm{R}>$

Warm growth medium to $37^{\circ} \mathrm{C}$ prior to cell culture.

Tris- $\mathrm{HCl}$ (50 mm, pH 9.5, sterile)

Dissolve $12.1 \mathrm{~g}$ of Trizma base in $200 \mathrm{~mL}$ of $\mathrm{dH}_{2} \mathrm{O}$. Adjust $\mathrm{pH}$ to 9.5 with $\mathrm{HCl}$.

Trypan blue (Invitrogen 15250-061)

Trypsin stock $(30,000 \mathrm{U} / \mathrm{mL})$

Dissolve trypsin (Sigma-Aldrich T9935) at 30,000 U/mL in EBSS. Filter through a 0.22- $\mu \mathrm{m}$ filter. Make 200- $\mu \mathrm{L}$ aliquots and store at $-80^{\circ} \mathrm{C}$.

Equipment

Centrifuge (tabletop, with 15 - and 50-mL conical tube adaptors)

Dissection equipment

Dissection microscope

Forceps (\#5 and \#55; Fine Science Tools 11251-20 and 11255-20)

Retina spatula or probe to scoop retina (Fine Science Tools 10094-13)

Scalpel blade (\#11) and scalpel blade handle (Fine Science Tools 10003-12)

Scissors (large, for decapitation) (ROBOZ RS-6820)

Scissors (small, curved) (e.g., ROBOZ RS-5603 for rat or Fine Science Tools 15011-12 for mouse)

Hemocytometer slide (Hausser Scientific 3110)

Nylon mesh filters (AmazonSupply 7050-1220-000-10)

Cut the nylon mesh into 3-inch squares, wrap in small packets of foil and autoclave.

Petri dishes (6-cm) (BD Falcon 351007)

Petri dishes (10- and 15-cm) (Falcon or Nunc)

Syringe filters $(0.22-\mu \mathrm{m})$

Tissue culture incubator $\left(37^{\circ} \mathrm{C} ; 10 \% \mathrm{CO}_{2}\right)$ 
Tubes (conical) (15- and 50-mL)

Tubes (universal) $(30-\mathrm{mL})$

Water bath $\left(37^{\circ} \mathrm{C}\right)$

METHOD

An overview of the method is provided in Figure 1. It is a 2-d procedure; Steps 1-4 are performed on the first day.

Preparation

1. Add the secondary antibodies to the panning dishes as follows.

\section{For Rat RGCs}

i. Prepare two antibody-coated $15-\mathrm{cm}$ Petri dishes for negative selection by adding $60 \mu \mathrm{L}$ of goat anti-rabbit IgG $(\mathrm{H}+\mathrm{L})$ and $20 \mathrm{~mL}$ of $50 \mathrm{~mm}$ Tris- $\mathrm{HCl}(\mathrm{pH} 9.5)$ per dish.

ii. Prepare one antibody-coated $10-\mathrm{cm}$ Petri dish for positive selection by adding $30 \mu \mathrm{L}$ of goat anti-mouse IgM ( $\mu$-chain specific) and $10 \mathrm{~mL}$ of $50 \mathrm{~mm}$ Tris- $\mathrm{HCl}(\mathrm{pH} 9.5)$.

\section{For Mouse RGCs}

iii. Prepare one antibody-coated 10 -cm Petri dish for positive selection by adding $30 \mu \mathrm{L}$ of goat anti-mouse $\operatorname{IgG}+\operatorname{IgM}(\mathrm{H}+\mathrm{L})$ and $10 \mathrm{~mL}$ of $50 \mathrm{~mm}$ Tris- $\mathrm{HCl}(\mathrm{pH} 9.5)$.

2. Swirl the plates until the surfaces are evenly coated by the antibody-Tris solution.

3. Incubate the panning plates overnight at $4^{\circ} \mathrm{C}$.

Plates are hydrophobic to begin with, but after coating overnight, plates become visibly hydrophilic. If plates are needed immediately, a quick but not ideal way of making plates is to coat with secondary antibodies for $2 \mathrm{~h}$ at $37^{\circ} \mathrm{C}$. For best results, however, it is preferable to coat the plates with secondary antibodies overnight.

4. Prepare the glass coverslips as follows.

i. Place 15 to 20 ethanol-washed glass coverslips in a Petri dish.

ii. Rinse the glass coverslips three times with sterile $\mathrm{H}_{2} \mathrm{O}$ in the Petri dish.

iii. After the last rinse, suction away any remaining $\mathrm{H}_{2} \mathrm{O}$ and separate the coverslips such that they do not touch each other or the sides of the dish.

iv. Allow the coverslips to completely air-dry. This should take 5-10 min after aspiration.

v. Carefully add $100 \mu \mathrm{L}$ of $1 \times$ PDL to the center of each coverslip. The PDL solution should cover the entire surface of the coverslip.

vi. Incubate the coverslips for 30-45 min at room temperature.

vii. Rinse the coverslips three times with sterile $\mathrm{H}_{2} \mathrm{O}$ and aspirate until dry.

viii. Dilute the mouse laminin $(1 \mathrm{mg} / \mathrm{mL})$ to a final concentration of $50 \mu \mathrm{g} / \mathrm{mL}$ by adding $10 \mu \mathrm{L}$ of laminin stock to $5 \mathrm{~mL}$ of Neurobasal medium. Mix well and add $100 \mu \mathrm{L}$ of the diluted laminin solution to each coverslip. Place in a $37^{\circ} \mathrm{C}$ incubator overnight.

5. Prepare three $15-\mathrm{mL}$ conical tubes as follows.

i. To one tube, add $10 \mathrm{~mL}$ of D-PBS and label as "Papain."

ii. To a second tube, add $9 \mathrm{~mL}$ of D-PBS and label as "low-ovo."

iii. To a third tube, add $5 \mathrm{~mL}$ of D-PBS and label as "high-ovo."

6. Add $10-15 \mathrm{~mL}$ of EBSS to a $10-\mathrm{cm}$ Petri dish and warm in a $37^{\circ} \mathrm{C}$ incubator for at least $2 \mathrm{~h}$. 
A. Winzeler and J.T. Wang

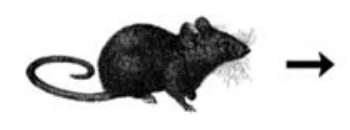

Obtain rodents and prepare all solutions, etc.

Steps 1-11 $1 \mathrm{~h}$, day $1 ; 15-30 \mathrm{~min}$, day 2

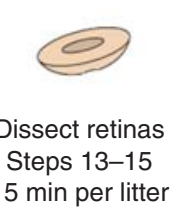

Steps $13-15$
15 min per litter

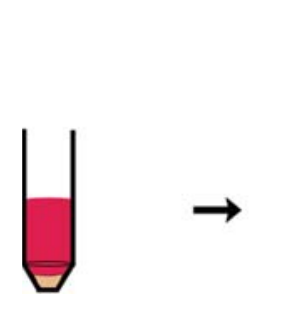

Papain digest tissue

Steps 16-23

Rat: 30 min digestion; 45 min total Mouse: 45 min digestion; $1 \mathrm{~h}$ total

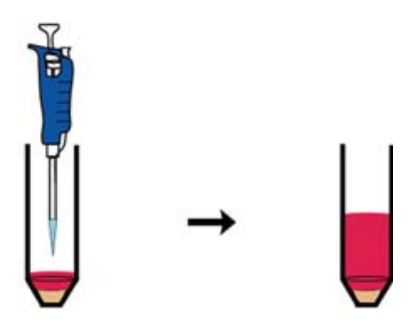

Trituration and low-ovo incubation Steps 24-26

Rat: 25 min Mouse: $15 \mathrm{~min}$

$$
\text { Steps } 27-31
$$

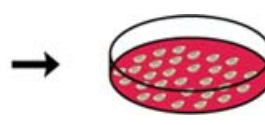

Remove membranes Step 15

10-15 min per litter
Preparation

\& dissection

Steps 1-15

$1-1.5 \mathrm{~h}$

Low-ovo and high-ovo spins, rinsing and filtering cells

$2 \times 10-$ min spins; $30-45$ min total

Dissociation Steps 16-31

2-2.5 h

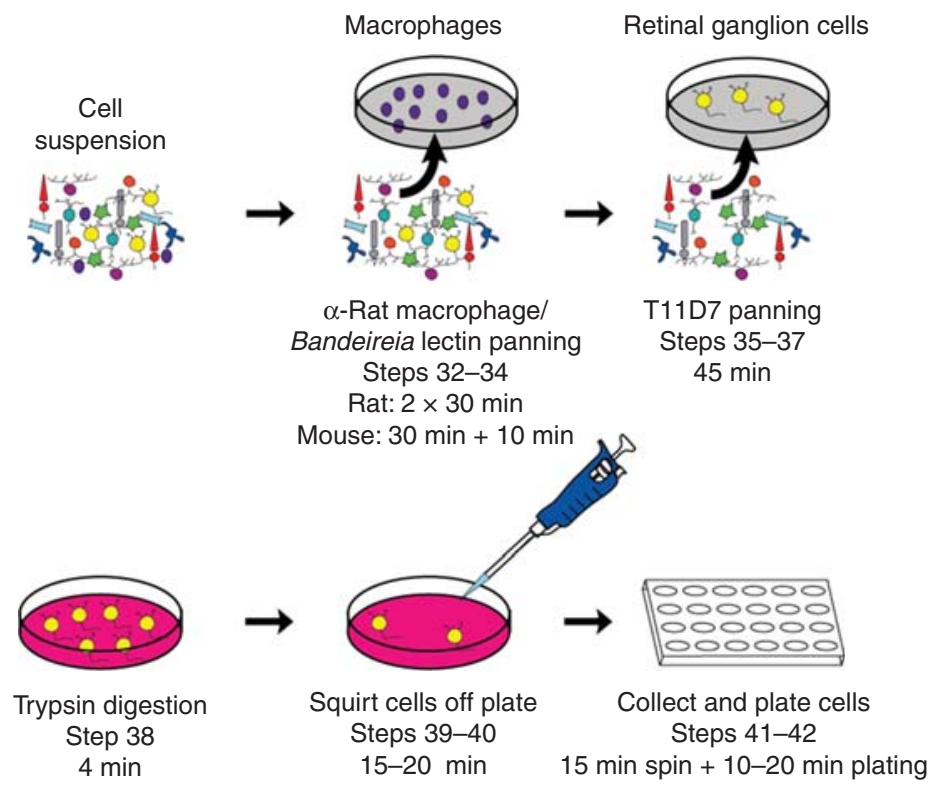

Trypsinization \& plating Steps 38-42 $1-1.5 \mathrm{~h}$

FIGURE 1. Purification of RGCs by immunopanning with anti-Thy1.

7. Prepare the panning dishes by coating with primary antibodies as follows.

\section{For Rat RGCs}

i. Rinse both $15-\mathrm{cm}$ negative selection plates prepared in Step 1.i three times with D-PBS.

ii. Rinse the single 10-cm positive selection plate prepared in Step 1.ii with D-PBS. Add $10 \mathrm{~mL}$ of Thyl.1 hybridoma supernatant.

iii. Swirl to evenly coat plastic.

iv. Let plates sit at least $2 \mathrm{~h}$ at room temperature.

\section{For Mouse RGCs}

v. Make two new 15-cm plates for negative selection by adding $20 \mu \mathrm{L}$ of BSL-1 and $20 \mathrm{~mL}$ of $\mathrm{D}$-PBS to each plate for at least $2 \mathrm{~h}$. 


\section{Dissection}

vi. Rinse the $10-\mathrm{cm}$ positive selection plate prepared in Step 1.iii three times with D-BPS. Add $10 \mu \mathrm{L}$ of mouse Thy1.2 antibody to a mixture of $9 \mathrm{~mL}$ of D-PBS plus $1 \mathrm{~mL}$ of $0.2 \%$ BSA.

vii. Swirl to evenly coat plastic.

viii. Let plates sit at least $2 \mathrm{~h}$ at room temperature.

Bandeireia lectin is an effective way to remove contaminating cell types. However, at high concentrations or when cells are incubated for long periods of time, it is also capable of binding to RGCs. Thus, care must be taken to check that the negative panning plates containing BSL-1 have not bound large numbers of RGCs. Although it is not in the protocol, BSL-1 can also be used as an alternative to anti-rat macrophage antibody for rat RGC preps. The steps are the same as those of the mouse preparation.

The Thy1.2 antibody used for mouse RGC preps contains azide, which is toxic to cells. Thus, Thy 1.2 plates must be washed thoroughly prior to exposure to cells (Step 34.ii).

8. Prepare the low-ovo and high-ovo solutions.

i. Add $2 \mu \mathrm{L}$ of $1 \mathrm{~N} \mathrm{NaOH}$ and $1 \mathrm{~mL}$ of low-ovo stock to the tube with $9 \mathrm{~mL}$ of D-PBS from Step 5.ii.

ii. Add $2 \mu \mathrm{L}$ of $1 \mathrm{~N} \mathrm{NaOH}$ and $1 \mathrm{~mL}$ of high-ovo stock to the tube with $5 \mathrm{~mL}$ of D-PBS from Step 5.iii.

Ovomucoid solutions are used to inhibit papain activity.

9. Prepare the panning buffer by combining $18 \mathrm{~mL}$ of D-PBS, $2 \mathrm{~mL}$ of $0.2 \% \mathrm{BSA}$, and $200 \mu \mathrm{L}$ of insulin in a universal tube.

10. Prepare a 30\% FCS solution by filtering $6 \mathrm{~mL}$ of FCS into $14 \mathrm{~mL}$ of D-PBS in a universal tube.

11. Prepare the RGC growth medium and warm in a $37^{\circ} \mathrm{C}$ incubator.

The dissection process is critical to obtaining optimal yield. Retinas that are removed in many small pieces will be lost to the aspiration step prior to trituration. Thus, it is important to dissect out intact retinas to maximize yield. An illustration of Steps 13-15 is provided in online Movie 1 at cshprotocols.cshlp.org.

12. Euthanize a rat or mouse by $\mathrm{CO}_{2}$ or direct decapitation.

13. Using a small scissor, cut away the skin covering the eyeball.

14. With the scalpel, make a horizontal slice across the exposed cornea starting at the lateral midpoint; the depth of the slit should be no more than $0.5 \mathrm{~cm}$ below the top of the cornea to avoid damaging the retina. Remove the lens with the back of the scalpel blade. Use the scalpel blade to gently scrape away the translucent vitreous humor that may appear after making the slit.

15. Holding the eye socket with forceps, use a flat instrument to gently scoop out the retina and place it in a 6-cm Petri dish containing D-PBS. Under a dissection microscope, use forceps to gently pull out and remove the membrane attached to the retina.

Often, blood vessels are visible coursing through the membrane.

16. Add 165 units of papain to the tube with $10 \mathrm{~mL}$ of D-PBS from Step 5.i. Shake the tube gently and warm in a $37^{\circ} \mathrm{C}$ water bath for $5 \mathrm{~min}$ or until the papain is dissolved.

17. Measure out $2 \mathrm{mg}$ of L-cysteine and add it to the tube containing papain. Add $\sim 10 \mu \mathrm{L}$ of $1 \mathrm{~N}$ $\mathrm{NaOH}$ to neutralize the $\mathrm{pH}$.

The addition of L-cysteine is necessary for the activation of the papain. Failure to add L-cysteine will decrease the efficacy of papain-mediated proteolysis.

The strength of papain solutions can vary widely from lot to lot and can affect the final yield. Although this protocol is based on the unit strength provided, each lot of papain should be tested empirically to determine optimal concentration.

18. Add $100 \mu \mathrm{L}$ of DNase I stock to the tube containing papain. 
A. Winzeler and J.T. Wang

19. Add $100 \mu \mathrm{L}$ of DNase I stock to the tube containing low ovo solution prepared in Step 8.i.

20. Filter the papain solution into a universal tube.

21. Remove the excess D-PBS from the Petri dish containing the retina. Pour the retina into the tube containing filtered papain solution. Incubate in a water bath for $30 \mathrm{~min}$ (for rat retina) or $45 \mathrm{~min}$ (for mouse retina). Gently shake the tube to mix every $15 \mathrm{~min}$.

22. Aspirate the papain supernatant and add $4 \mathrm{~mL}$ of the low-ovo solution to the retina. Let the tissue settle in the tube for $1 \mathrm{~min}$.

23. For rat RGCs only, add $80 \mu \mathrm{L}$ of anti-rat macrophage to the remaining $6 \mathrm{~mL}$ of low-ovo solution. (For mouse RGCs, proceed to Step 24.)

\section{Trituration}

An illustration of Steps 24-25 is provided in online Movie 2 at cshprotocols.cshlp.org.

24. Aspirate the low-ovo solution and add $2 \mathrm{~mL}$ of low-ovo + anti-macrophage solution (if rat) or low-ovo solution (if mouse) to the retina. Using a 1-mL pipette, gently triturate the retina three to four times, and then let the tissue settle for $1 \mathrm{~min}$.

25. After $1 \mathrm{~min}$, transfer the supernatant to a new $15-\mathrm{mL}$ tube. Again add $1 \mathrm{~mL}$ of low-ovo + antimacrophage or low-ovo solution to the tube containing the retina, gently triturate the retina three to four times, and let the tissue settle for $1 \mathrm{~min}$. Repeat until all of the low-ovo solution has been used.

Trituration is performed in low-ovo solution because cells survive trituration better in a lower protein solution. High-ovo is subsequently used to fully quench any residual papain enzymatic activity.

Production of bubbles must be minimized, especially during trituration and recovery of trypsinized cells, to ensure optimal cell health.

26. For rat cells only: Incubate the retinas for an additional $10 \mathrm{~min}$ at room temperature to allow binding of the macrophage antibody.

27. Centrifuge the tissue at $1000 \mathrm{rpm}$ for $12 \mathrm{~min}$ at $25^{\circ} \mathrm{C}$.

28. For mouse cells only: During Step 27, rinse the two 15-cm plates prepared in Step 7.v with D-PBS and block each plate with $10 \mathrm{~mL}$ of $0.2 \%$ BSA.

29. Aspirate the supernatant and resuspend the cells in the high-ovo solution prepared in Step 8.ii. Centrifuge at $1000 \mathrm{rpm}$ for $12 \mathrm{~min}$ at $25^{\circ} \mathrm{C}$.

\section{Panning}

30. Resuspend the cells in panning buffer. Bring the volume up to $15 \mathrm{~mL}$.

31. Filter the cell suspension through an autoclaved $20-\mu \mathrm{m}$ nylon mesh.

i. First, form a cone with the mesh on top of a $50-\mathrm{mL}$ tube, then prewet the mesh with $1 \mathrm{~mL}$ of panning buffer.

ii. Transfer the cell suspension through the mesh filter, $1 \mathrm{~mL}$ at a time.

iii. Filter the remaining panning buffer through the mesh to rinse off any cells still on the mesh. Filtering the cell suspension through the nylon mesh gets rid of large debris and tissues, and helps break cell clumps into single cells, which will improve binding during the positive selection step (Step 35).

32. Transfer the cells to the first negative panning plate.

i. For rat cells, pan for $20 \mathrm{~min}$.

ii. For mouse cells, pan for $30 \mathrm{~min}$, shaking the plate every $15 \mathrm{~min}$. 


\section{Trypsinization}

33. Transfer the cells to the second negative panning plate.

i. For rat cells, pan for $45 \mathrm{~min}$, shaking the plate every $15 \mathrm{~min}$.

ii. For mouse cells, pan for $10 \mathrm{~min}$, or until the RGCs can be seen binding to the plate.

We have found that mouse RGCs purified using this protocol may contain amacrine cells. If maximal purity of mouse RGCs is desired, such as for gene expression or proteomic studies, one can further deplete the amacrine population from the cell suspension by targeting VC1.1, an amacrine surface antigen (Goldberg et al. 2002). Transfer the cell suspension to an anti-VC1.1 antibody-coated negative dish (add $10 \mu \mathrm{L}$ VC1.1 antibody to $30 \mathrm{~mL}$ of $50 \mathrm{~mm}$ Tris- $\mathrm{HCl}$ in a 10-cm dish) and pan for another 30 min (shaking the plate every $15 \mathrm{~min}$ ) before proceeding to the positive panning step. This will help pull down additional amacrine cells.

When panning, varying amounts of panning buffer can be used (10-20 mL/plate). Larger volumes will result in less clumping of cells within the cell suspension during panning, but have a tendency to spill once the cells are transferred to the smaller positive panning dishes.

34. Just before transferring the cells to the positive panning plate (Step 35), rinse the plate with D-PBS.

i. For rat cells, discard the Thy1.1 hybridoma supernatant and rinse the plate three times with D-PBS.

ii. For mouse cells, discard the Thyl.2 antibody solution and rinse the plate nine times with D-PBS (Thy1.2 antibody contains azide!).

35. Transfer the cells to the positive panning plate and pan for $45 \mathrm{~min}$ (for both rat and mouse RGCs), shaking the plate every 15 min.

An illustration of Steps 39 and 40 is provided in online Movie 3 at cshprotocols.cshlp.org.

36. In the last $15 \mathrm{~min}$ of panning, add $100 \mu \mathrm{L}$ of trypsin stock to $4 \mathrm{~mL}$ of warmed EBSS from Step 6.

37. Wash the positive panning dish six times with D-PBS. Examine the dish under the microscope to ensure only adherent cells remain.

38. Rinse the dish with the remaining EBSS from Step 6, then add the trypsin-EBSS solution. Incubate the dish at $37^{\circ} \mathrm{C}$ for $4 \mathrm{~min}$.

$\mathrm{Ca}^{2+}$ inhibits trypsin activity, so the plate must be rinsed with $\mathrm{Ca}^{2+}$-free EBSS solution before the addition of trypsin.

Optimal trypsinization time should be determined with each new batch of stock trypsin solution and should correspond to the point at which a large percentage of cells on the plate can be easily released by gentle pipetting. Trypsinization times that are either too short or too long can result in reduced cell viability.

39. Add $2 \mathrm{~mL}$ of $30 \%$ FCS to the panning dish. Gently squirt the solution against the plate to rinse off the adherent RGCs. Transfer the cell solution to a new $50-\mathrm{mL}$ conical tube containing $1 \mathrm{~mL}$ of $30 \%$ FCS.

Adding $1 \mathrm{~mL}$ of FCS to the tube before the cells are added ensures that the cells first contact liquid rather than a dry surface.

Production of bubbles must be minimized, especially during trituration and recovery of trypsinized cells to ensure optimal cell health.

40. Add another $5 \mathrm{~mL}$ of FCS to the panning dish. Repeat squirting and transferring cells until all the FCS has been used. Check the dish under the microscope to confirm that the adherent cells have been washed off.

Plating

41. Remove a $50-\mu \mathrm{L}$ aliquot of cell solution and quantify yield using a hemocytometer slide and trypan blue. Centrifuge the remaining cells at $1000 \mathrm{rpm}$ for $12 \mathrm{~min}$. 
A. Winzeler and J.T. Wang

$$
\begin{aligned}
& \text { Expected yields are as follows: } \\
& \text { - } \sim 30,000 \text { cells/P7 rat retina } \\
& \text { - } \sim 15,000 \text { cells/P7 mouse retina }
\end{aligned}
$$

42. Resuspend the cells in prewarmed RGC growth medium and plate at the desired density on the PDL- and laminin-coated coverslips prepared in Step 4. Cell density can vary depending on desired experimental conditions: Plate $<5000$ cells per 24 -well plate for low density, and $>30,000$ cells per 24-well plate for high density.

To ensure optimal osmolarity and conditions for RGC survival and viability, cells are cultured in RGC growth medium, an enriched serum-free growth medium that contains 50\% DMEM and 50\% Neurobasal medium. For more information on rodent RGCs as a model system and details about their serum-free culture requirements, see Purification and Culture of Retinal Ganglion Cells (Winzeler and Wang 2013b).

\section{RECIPES}

BDNF Stock $(50 \mu \mathrm{g} / \mathrm{mL})$

1. Prepare a master BDNF stock $(1 \mathrm{mg} / \mathrm{mL})$ by resuspending $1 \mathrm{mg}$ of human brainderived neurotrophic factor in powder form (BDNF; Peprotech 450-02) in $1 \mathrm{~mL}$ of cold, sterile $0.2 \%$ BSA (Sigma-Aldrich A-4161) that was prepared in D-PBS (Gibco 14287). Make 200- $\mu \mathrm{L}$ aliquots of the master stock, flash-freeze in liquid nitrogen, and store at $-80^{\circ} \mathrm{C}$.

2. To make a working BDNF stock, thaw a $200-\mu \mathrm{L}$ aliquot of master stock on ice. At the same time, chill $3.8 \mathrm{~mL}$ of sterile $0.2 \%$ BSA solution on ice. Once chilled, add the master BDNF stock to the $0.2 \%$ BSA solution and mix well, but gently, to avoid foaming. Make $20-\mu \mathrm{L}$ working aliquots and flash-freeze in liquid nitrogen. Store at $-80^{\circ} \mathrm{C}$.

\section{Ciliary Neurotrophic Factor $(10 \mu \mathrm{g} / \mathrm{mL})$}

To prepare, dilute ciliary neurotrophic factor (CNTF; Peprotech $450-13$ ) to $10 \mu \mathrm{g} / \mathrm{mL}$ in sterile $0.2 \%$ BSA that was prepared with D-PBS (Gibco 14287). Make 20- $\mu \mathrm{L}$ aliquots, flash-freeze in liquid nitrogen, and store at $-80^{\circ} \mathrm{C}$.

\begin{tabular}{|c|c|c|}
\hline Reagent & $\begin{array}{l}\text { Amount } \\
\text { (for } 20 \mathrm{~mL} \text { ) }\end{array}$ & Final \\
\hline Neurobasal medium (Gibco 21103-049) & $9.5 \mathrm{~mL}$ & \\
\hline DMEM (Gibco 11960-044) & $9.5 \mathrm{~mL}$ & \\
\hline Insulin stock $(0.5 \mathrm{mg} / \mathrm{mL})<\mathrm{R}>$ & $200 \mu \mathrm{L}$ & $5 \mu \mathrm{g} / \mathrm{mL}$ \\
\hline Sodium pyruvate (100 mm; Gibco 11360-070) & $200 \mu \mathrm{L}$ & $110 \mu \mathrm{g} / \mathrm{mL}$ \\
\hline Penicillin-streptomycin (100×; Gibco 15140-122) & $200 \mu \mathrm{L}$ & $\begin{array}{r}100 \mathrm{U} / \mathrm{mL} \\
(\text { penicillin) } \\
100 \mu \mathrm{g} / \mathrm{mL} \\
\text { (streptomycin) }\end{array}$ \\
\hline SATO supplement $(100 \times)<\mathrm{R}>$ & $200 \mu \mathrm{L}$ & $1 \times$ \\
\hline Thyroxine (T3) stock $(4 \mu \mathrm{g} / \mathrm{mL})<\mathrm{R}>$ & $200 \mu \mathrm{L}$ & $40 \mathrm{ng} / \mathrm{mL}$ \\
\hline L-glutamine (200 mM; Gibco 25030-081) & $200 \mu \mathrm{L}$ & $292 \mu \mathrm{g} / \mathrm{mL}$ \\
\hline $\begin{array}{l}\text { NS21 supplement }(50 \times)(\text { R\&D Systems AR008; see } \\
\quad \text { Chen et al. 2008) }\end{array}$ & $400 \mu \mathrm{L}$ & $1 \times$ \\
\hline NAC stock $(5 \mathrm{mg} / \mathrm{mL})<\mathrm{R}>$ & $20 \mu \mathrm{L}$ & $5 \mu \mathrm{g} / \mathrm{mL}$ \\
\hline
\end{tabular}

DMEM-Sato Base Growth Medium (with NB)

1. Combine the following:

2. Filter through a rinsed $0.22-\mu \mathrm{m}$ filter to sterilize. 


\section{Ethanol-Washed Glass Coverslips}

Extensively wash 12-mm glass coverslips (Carolina Biological Supply 633029) in 70\% ethanol. Perform the washes on a platform shaker in a beaker, with enough motion to lightly agitate the coverslips but not break too many. Wash the coverslips for about 1 mo, exchanging the ethanol approximately every day. (It is fine to skip some exchanges.) Store the washed coverslips in $70 \%$ ethanol until use.

\section{Forskolin Stock $(4.2 \mathrm{mg} / \mathrm{mL})$}

To prepare, add $1 \mathrm{~mL}$ of sterile DMSO to a 50-mg bottle of forskolin (Sigma-Aldrich F6886) and pipette up and down until the powder is fully resuspended. Transfer to a 15$\mathrm{mL}$ conical tube and add an additional $11 \mathrm{~mL}$ of DMSO to achieve a final concentration of $4.2 \mathrm{mg} / \mathrm{mL}$. Store in 20 - and $80-\mu \mathrm{L}$ aliquots at $-20^{\circ} \mathrm{C}$.

\section{High-Ovomucoid Stock (6×)}

1. Dissolve the following in $160-180 \mathrm{~mL}$ of Dulbecco's phosphate-buffered saline (D-PBS; Invitrogen 14287-080).

Amount

\begin{tabular}{lcc} 
Reagent & (for $200 \mathrm{~mL})$ & Final concentration \\
\hline BSA (Sigma-Aldrich A-8806) & $6 \mathrm{~g}$ & $30 \mathrm{mg} / \mathrm{mL}$ \\
Trypsin inhibitor & $6 \mathrm{~g}$ & $30 \mathrm{mg} / \mathrm{mL}$
\end{tabular}

(Worthington LS003086)

2. Adjust the $\mathrm{pH}$ to 7.4 with $10 \mathrm{~N} \mathrm{NaOH}$. Bring the volume to $200 \mathrm{~mL}$ with D-PBS, and then filter-sterilize.

3. Make $1-\mathrm{mL}$ aliquots and store them at $-20^{\circ} \mathrm{C}$.

Insulin Stock $(0.5 \mathrm{mg} / \mathrm{mL})$

To $20 \mathrm{~mL}$ of sterile water, add $10 \mathrm{mg}$ of insulin (Sigma-Aldrich I6634) and $100 \mu \mathrm{L}$ of $1.0 \mathrm{~N} \mathrm{HCl}$. Mix well. Filter through a $0.22-\mu \mathrm{m}$ filter. Store at $4^{\circ} \mathrm{C}$ for $4-6 \mathrm{wk}$.

Low-Ovomucoid Stock Solution $(10 \times)$

To prepare, add $3 \mathrm{~g}$ of BSA (Sigma-Aldrich A8806) to $150 \mathrm{~mL}$ D-PBS. Mix well. Add $3 \mathrm{~g}$ of trypsin inhibitor (Worthington LS003086) and mix to dissolve. Add $\sim 1 \mathrm{~mL}$ of $1 \mathrm{~N}$ $\mathrm{NaOH}$ to adjust the $\mathrm{pH}$ to 7.4. Bring the volume to $200 \mathrm{~mL}$ with D-PBS. Filter-sterilize through a $0.22-\mu \mathrm{m}$ filter. Make $1.0-\mathrm{mL}$ aliquots and store at $-20^{\circ} \mathrm{C}$.

\section{NAC Stock (5 mg/mL)}

To prepare, dissolve $50 \mathrm{mg}$ of $\mathrm{N}$-acetyl-L-cysteine (NAC) powder (Sigma-Aldrich A8199) in $10 \mathrm{~mL}$ of Neurobasal Medium (Gibco/Life Technologies 21103). (The solution will be yellowish.) Filter through a $0.22-\mu \mathrm{m}$ filter. Prepare 20 - and $80-\mu \mathrm{L}$ aliquots and store them at $-20^{\circ} \mathrm{C}$.

\section{RGC Growth Medium}

DMEM-Sato base growth medium (with NB) $<\mathrm{R}>\quad 20 \mathrm{~mL}$

Forskolin stock $(4.2 \mathrm{mg} / \mathrm{mL})<\mathrm{R}>\quad 20 \mu \mathrm{L}$

BDNF stock $(50 \mu \mathrm{g} / \mathrm{mL})<\mathrm{R}>\quad 20 \mu \mathrm{L}$

Ciliary neurotrophic factor $(10 \mu \mathrm{g} / \mathrm{mL})<\mathrm{R}>\quad 20 \mu \mathrm{L}$

Warm growth medium to $37^{\circ} \mathrm{C}$ prior to cell culture, or store at $4^{\circ} \mathrm{C}$ for up to $3 \mathrm{~d}$. 
A. Winzeler and J.T. Wang

\section{SATO Supplement $(100 \times)$}

1. Prepare the following stock solutions (these should be made fresh; do not reuse).

- Combine $5 \mathrm{mg}$ of progesterone (Sigma-Aldrich P8783) and $200 \mu \mathrm{L}$ of ethanol to make a progesterone stock solution.

- Combine $4 \mathrm{mg}$ of sodium selenite (Sigma-Aldrich S5261), $10 \mu \mathrm{L}$ of $1 \mathrm{~N} \mathrm{NaOH}$, and $10 \mathrm{~mL}$ of Dulbecco's modified Eagle's medium (DMEM; Gibco/Life Technologies 11960-044) to make a sodium selenite stock solution.

2. Combine the following:

\begin{tabular}{lcc} 
Reagent & $\begin{array}{c}\text { Quantity } \\
\text { (for 200 mL) }\end{array}$ & $\begin{array}{c}\text { Final concentration } \\
(100 \times)\end{array}$ \\
\hline BSA (Sigma-Aldrich A4161) & $2 \mathrm{~g}$ & $10 \mathrm{mg} / \mathrm{mL}$ \\
Transferrin (Sigma-Aldrich T1147) & $2 \mathrm{~g}$ & $10 \mathrm{mg} / \mathrm{mL}$ \\
Putrescine (Sigma-Aldrich P5780) & $320 \mathrm{mg}$ & $1.6 \mathrm{mg} / \mathrm{mL}$ \\
Progesterone stock solution & $50 \mu \mathrm{L}$ & $6 \mu \mathrm{g} / \mathrm{mL}$ \\
Sodium selenite stock solution & $2 \mathrm{~mL}$ & $4 \mu \mathrm{g} / \mathrm{mL}$
\end{tabular}

3. Bring to a total volume of $200 \mathrm{~mL}$ in DMEM, and then filter-sterilize. Aliquot and store at $-20^{\circ} \mathrm{C}$.

\section{Thyroxine (T3) Stock $(4 \mu \mathrm{g} / \mathrm{mL})$}

Dissolve $3.2 \mathrm{mg}$ of 3,3',5-triiodo-L-thyronine sodium salt (T3; Sigma-Aldrich T6397) in $400 \mu \mathrm{L}$ of $0.1 \mathrm{~N} \mathrm{NaOH}$. Add $10 \mu \mathrm{L}$ of T3 solution to $20 \mathrm{~mL}$ of Dulbecco's phosphatebuffered saline (D-PBS; Gibco 14287). Filter through a $0.22-\mu \mathrm{m}$ filter, discarding the first $10 \mathrm{~mL}$. Make $200-\mu \mathrm{L}$ aliquots and store at $-20^{\circ} \mathrm{C}$.

\section{ACKNOWLEDGMENTS}

We thank Maria Fabian for technical assistance, and Mariko Howe, Amanda Brosius-Lutz, and Jennifer Zamanian for reading and comments on the protocol.

\section{REFERENCES}

Chen Y, Stevens B, Chang J, Milbrandt J, Barres BA, Hell JW. 2008. NS21: Re-defined and modified supplement B27 for neuronal cultures. J Neurosci Methods 171: 239-247.

Goldberg JL, Klassen MP, Hua Y, Barres BA. 2002. Amacrine-signaled loss of intrinsic axon growth ability by retinal ganglion cells. Science 296: 1860-1864.
Winzeler A, Wang JT. 2013a. Culturing hybridoma cell lines for monoclonal antibody production. Cold Spring Harb Protoc doi: 10.1101/pdb. prot074914.

Winzeler A, Wang JT. 2013b. Purification and culture of retinal ganglion cells. Cold Spring Harb Protoc doi: 10.1101/pdb.top070961. 


\section{Purification and Culture of Retinal Ganglion Cells from Rodents}

Alissa Winzeler and Jack T. Wang

Cold Spring Harb Protoc; doi: 10.1101/pdb.prot074906

\begin{tabular}{|c|c|}
\hline $\begin{array}{r}\text { Email Alerting } \\
\text { Service }\end{array}$ & Receive free email alerts when new articles cite this article - click here. \\
\hline $\begin{array}{r}\text { Subject } \\
\text { Categories }\end{array}$ & $\begin{array}{l}\text { Browse articles on similar topics from Cold Spring Harbor Protocols. } \\
\text { Immunoaffinity Purification ( } 49 \text { articles) } \\
\text { Immunoseparation ( } 31 \text { articles) } \\
\text { Mouse ( } 437 \text { articles) } \\
\text { Neural Cell Culture (57 articles) } \\
\text { Neuroscience, general ( } 357 \text { articles) } \\
\text { Other Laboratory Organisms ( } 68 \text { articles) }\end{array}$ \\
\hline
\end{tabular}

